\title{
DEMÔNIOS DA BRASILIDADE: NOTAS PARA UM NIILISMO TROPICAL $^{1}$
}

\author{
Rodrigo Barros Gewehr ${ }^{2}$
}

\begin{abstract}
Resumo: Este ensaio busca estabelecer algumas bases de reflexão sobre a possibilidade de se pensar uma brasilidade a partir do conceito de niilismo. Visa-se a compreender se seria viável uma aplicação específica desse conceito, no contexto brasileiro. A ideia do demoníaco entra em cena para dar conta do índice do imponderável em todo construto coletivo, salientando que as dinâmicas psíquicas, sejam elas individuais, sejam coletivas, se realizam na cultura em formas sobredeterminadas. Nessa busca de se pensar a brasilidade, propóe-se o entrelaçamento do niilismo com traços culturais já elencados por autores como Mário de Andrade, Gilberto Freyre, Sérgio Buarque de Holanda, entre outros.
\end{abstract}

Palavras-chave: Niilismo. Brasilidade. Traços culturais.

But nothing is ever lost, not even the blood pact with the devil.

(JUNG, 1990 [1954], p. 268).

\section{INTRODUÇÁO}

Talvez seja anacrônico pensar em termos de brasilidade, eco de ultrapassadas tentativas cientificistas de escanção artificial da vida em comum, seguidamente resultando em fantasmagorias, como atestam Gall, Galton e

\footnotetext{
${ }^{1}$ Este ensaio tem por base uma fala proferida em seminário de pesquisa da pós-graduação do Instituto de Psicologia da USP, em parceria com a UNIFESP, realizado entre os dias 15 e 17 de maio de 2017. Pelo convite e parceria de trabalho, agradeço aos professores Lineu Kohatsu e Marian Dias.

2 Professor no Instituto de Psicologia e no Programa de Pós-Graduaçâo em Filosofia da Universidade Federal de Alagoas (UFAL), Maceió, AL - Brasil. (D) https://orcid.org/0000-0002-3274-7032 E-mail: rodrigo.gewehr@ip.ufal.br.
}

https://doi.org/10.1590/0101-3173.2021.v44n3.27.p343

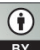


Lombroso. Tipologias são sempre dignas de desconfiança, tanto mais quando direcionadas à vida humana e à vida em comum. Há nelas algo de "[...] hieróglifo de linguagem morta" (UMBELINO, 2010, p. 309), o que alerta para as derivas latentes em todo esforço de abordagem a traços culturais. Pensar nesses termos é sem dúvida arriscado, e potencialmente perigoso, sobretudo se se considera o crescimento de ideologias de tipo nacionalista, espalhadas pelo mundo e na América Latina, provocando as gangrenas sociais que thes são próprias.

Mas não é disso que se trata aqui. Não se trata de elogio a forma nenhuma de nacionalismo, e menos ainda da construção de uma suposta unidade identitária que teria no termo "brasilidade" seu amálgama. Isso, no entanto, náo impede a fabricação de figuraçôes da vida em comum e, por mais que recusemos as cristalizaçóes identitárias, elas se configuram no convívio, impulsionadas por diferentes mitologias do coletivo.

Tendo isso em vista, não é possível escapar de certo grau de generalização, ao se pensar em termos sociológicos, e esta é uma dimensão inescapável da reflexão sobre a vida em comum. Todo conceito é um artifício; e, quando se trata de pensar um povo, essa artificialidade pode chegar às raias do arbitrário ou, ainda pior, converter-se em mero "[...] preconceito travestido de evidência científica." (SOUZA, 2015, p. 37). Se este é o corolário de uma tradição cientificista que reiteradamente confunde a parte pelo todo e universaliza suas conclusôes parciais, isso deveria nos impedir ou interditar qualquer reflexão de maior amplitude sobre o conjunto das açôes humanas, de um povo, de uma coletividade? E mais, as categorizaçóes já inventadas, na sempre dificultosa tarefa de compreender a brasilidade, são elas necessariamente um problema, ou se pode abordá-las de outro modo, compreendê-las a partir de visadas que não sejam mera reprodução de um culturalismo servil?

A unidade histórica escolhida é sempre arbitrária”, lembra Tolstói ao criticar a insistência de historiadores em sobrevalorizar alguns personagens como se fossem as decisivas molas propulsoras de fatos históricos. Foi a soma das vontades das pessoas que produziu a revolução e também Napoleão, acrescenta o autor, e esta soma "nunca se expressa na atividade de um personagem histórico. (TOLSTÓI, 2017 [1869], p. 991).

Tais personagens, no entanto, bem como o conjunto das açôes de um determinado episódio, expressam um movimento de fundo, as tendências homogêneas das pessoas, e isso constitui, ainda para Tolstói, uma unidade 
infinitesimal para observação. Assim, se cabe evitar com todo cuidado a reificação de personagens, e também de categorias de análise, resta ainda a possibilidade de observar os agenciamentos que constituem as ficções de um povo.

Não se trata aqui, pois, de propor uma tipologia a mais; nem de almejar a explicação, ou mesmo a compreensão do movimento vivo das gentes, por meio de categorias estanques. Se há algum valor nessa paixão da generalidade é seu caráter de caricatura, como será salientado adiante. As generalizaçôes possuem o mesmo vetor de exageração da caricatura, e é pela via do excesso que alguns traços mais marcantes acabam vindo à tona. Se não tomarmos isso como verdades reveladas a partir de um olhar transcendente, se não nos perdermos numa pretensa atitude de neutralidade que seria garantia de um saber desinteressado, parte do perigo se anula.

O psicologismo, sempre à espreita em tais abordagens, é despossuído de sua força mágica de encantamento e sedução pelo exercício mesmo de se reconhecer a construção de conceitos como parte da tessitura social, e uma figura a mais dos agenciamentos que capturam um povo. $\mathrm{O}$ perigo do “culturalismo brasileiro", tal como o define e denuncia Jessé Souza (2015), também não é o único desfecho possível, se guardarmos as ressalvas necessárias e o devido grau de desconfiança nas categorias. Não se trata, portanto, de buscar explicação do caráter de um povo, em função de fórmulas cujas taxonomias são evidentemente arbitrárias (UMBELINO, 2010). Trata-se, antes, desse exercício inglório de pensar em termos de unidades infinitesimais, e do que nestas há também de caricato; até que ponto a caricatura nos serve de espelho, a partir de que momento se cristaliza em estereótipo.

Discernir traços característicos de um povo é, nesse sentido, fundamentalmente ficção. Jamais se poderá alcançar a quintessência de uma coletividade; e a ideia mesma de essência de um povo é fabricação - nalguns casos, falsificação pura e simples. Isso não impede Tolstói (2017 [1869], p. 873) de falar num ar russo ou nas "[...] misteriosas correntes da vida popular russa." Isso tampouco impede Machado de Assis (1906, p. 129), em elogio feito a José de Alencar, de afirmar que, neste, "[...] há um modo de ver e de sentir, que dá a nota intima da nacionalidade", ou ainda a Augusto dos Anjos (2001 [1912], p. 69) de cantar "[...] a vibração bruta da corda mais recôndita da alma brasileira.” Lima Barreto (2011 [1915]) vai também estender seu olhar crítico à alma nacional. Os exemplos poderiam seguir, tanto na literatura quanto na filosofia e nas ciências sociais, pois é de todo impossível desconsiderar a 
dimensão inercial das ações, sejam elas singulares, sejam coletivas, apesar das dificuldades todas que essa reflexão impóe, especialmente levando-se em conta a sobredeterminação das açôes humanas, na qual os fatores materiais atuam de maneira decisiva. ${ }^{3}$ As ficçôes, todavia, são também parte da tessitura da vida em comum e se materializam nas ações cotidianas.

Quer pela via da vida de colmeia, quer do suporte social, seria também falsificação da realidade o esquivar-se de uma apreensão de conjunto da vida em comum, assim como não se pode evitar a imprecisão inerente a uma tal abordagem. Estar atento a essa dimensáo inercial da ação humana não implica ceder a ideias como "déficit sociológico", "autoimagem folclórica do brasileiro", "subjetivismo", ou ao "mito da brasilidade" (SOUZA, 2015). Pelo contrário. As notas que seguem visam também a ressaltar as ambiguidades dos conceitos que se dedicam a pensar a brasilidade, sem negligenciar, por conseguinte, seu caráter de caricatura. E se nossa ação no mundo nos ultrapassa em grande medida, se somos muitas vezes e até estruturalmente suplantados por diferentes formas de contágio, podemos também pensar essas categorias de análise como uma expressão a mais daquilo que nos arrebata e move, apesar da disposição crítica que nutrimos, ou supomos nutrir. É nessa fronteira que se reinscreve a imagem do demoníaco, como índice do imponderável, daquilo que nos ultrapassa; pois, mesmo se nos cercamos de todos os cuidados, como distinguir ao certo quando a paixão da generalidade se torna uma patologia da generalização? O diabo, como se usa dizer, está nos detalhes.

A tradição ocidental é assolada por demônios de várias estirpes, desde longa data. Dos mediadores entre homens e deuses, que são os daimones gregos, aos demônios medievais - que o famoso manual dominicano Malleus maleficarum (KRAMER; SPRENGER, 1971 [1486]) insistia em afirmar que

\footnotetext{
3 "A questão de se determinar a hierarquia de valores que logra comandar uma sociedade específica exige a articulação da relação entre valores e estratificação social. Afinal, é a imbricação entre domínio material e ideológico e acesso diferencial a bens ideais ou materiais escassos que cumpre esclarecer." (SOUZA, 2015, p. 79). Disso não há dúvidas, e a realidade social cotidiana do Brasil o mostra largamente. No entanto, cabe questionar se é somente essa imbricaçáo que resta a esclarecer, ou se a ela não estão atrelados ainda outros fatores que também se apropriam dessa situaçấo estrutural. Noutros termos - e o presente ensaio segue o intuito de colocar essa questáo: explorar o estrato material do problema seria suficiente como resposta à complexidade dos afetos coletivos que transitam entre os espaços comuns e o foro intimo?
} 
não eram meros frutos da imaginação e sim entidades reais, o imaginário ligado ao demoníaco oscila entre o culto e o medo, entre o fascínio e a repulsa, marcado não somente pela crença como pelo que há de insistente, nessa imagem. Também nas figuraçôes oitocentistas e nas encarnaçóes coletivas do demoníaco, na primeira metade do século XX, vemos um mundo ainda assombrado pelo que há de incontrolável no cerne mesmo de nossas estratégias de delimitação e apreensão da vida. Compreendemos, de maneira obscura, que a complexidade dos processos vitais é bastante mais ampla do que nossos cálculos e toda a técnica de que dispomos para apreendê-la.

Seja na inquieta interação de partículas no plano microscópico, seja no intrincado dinamismo cósmico, passando ainda pelos movimentos coletivos e pela mais banal de nossas escolhas, há sempre um coeficiente de imponderável que nos obriga a renunciar às pretensóes de onipotência. Entretanto, um anseio de onipotência não cessa de se reeditar no modo como nos constituímos no confronto com a vida; e tal anseio alimenta, muitas vezes, nossas respostas às exigências do cotidiano.

Certo élan de realizar-se é parte inerente à possibilidade mesma da vida. Ressalta Nietzsche (1987 [1888], p. 57): “O pathos agressivo pertence tão necessariamente à força como o sentimento de retaliação e vingança à fraqueza." Há nessa articulação do pathos algo que pode derivar para o desenfreado, para uma paixão do excesso e da fúria. E sobre isso tampouco temos muito controle. Estando o pathos no fundamento de nossas açôes, o imponderável, para além de um coeficiente, é também aquilo que irrompe; opóe-se ou acelera; choca e extravasa. A ideia mesma de imponderável torna-se uma tentativa parcial de dar forma a atravessamentos radicais da experiência humana. Noutros termos, o imponderável pode ser visto como expressáo contemporânea do demoníaco.

Em 1936, Jung escreve um ensaio sobre Wotan, deus nórdico da fúria e da guerra, também dotado de um poder intuitivo. Wotan se apresenta, num primeiro nível de análise, como personificação do furor teutonicus, o qual, no momento da escrita do texto, estava conduzindo a Alemanha, a largos passos, rumo ao desastre que conhecemos.

O autor suíço busca dar conta de um aspecto da psique representado pela ideia da Ergriffenheit, condição de estar profundamente emocionado, capturado ou, ainda, possuido - aspecto ao qual Jung dá ênfase no referido ensaio, salientando o caráter demoníaco inerente a essa imagem. Para essa 
condição se estabelecer, é preciso que se constitua uma relação entre aquele que é possuido (Ergriffener) e aquele que possui (Ergreifer). Não somente como parte de uma configuração de época, que via na psicologia das massas uma forma de compreensão dos movimentos coletivos, Jung enfatiza também o índice do imponderável. Os acontecimentos sociais, observados a partir dessa combinação, podem se tornar incontroláveis, por conta do conjunto de ações que são mobilizadas num dado momento, e isso aponta, por sua vez, para a autonomia dos processos psíquicos e sociais.

Para além dos elementos históricos e mitológicos discutidos por Jung (1978a [1936]), um eixo central de sua análise está no fato de essas imagens personificarem valências psíquicas, as quais nos arrastam para a esfera dos arranjos afetivos inconscientes. Todo esse potencial inconsciente de atividade psíquica nos conduz, imperativamente, para a necessidade de se desfazer a equivalência artificial entre consciência e psique. "Nossa mania de explicaçôes racionais está obviamente enraizada no medo da metafísica, pois ambas sempre foram irmãs hostis." (JUNG, 1978a [1936], p. 185). Jung indica a necessidade de se considerar, na efetivação dos processos psíquicos e culturais, elementos que escapam ao controle de nossos instrumentais mais corriqueiros, dos quais a razão e o entendimento são condição e modo operacional, respectivamente.

Embora acontecimentos que escapem ao controle desse aparato técnico sejam muitas vezes relegados ao esquecimento ou ao descrédito, isso não os impede de operar nas entrelinhas de nosso ceticismo. Pensemos, para permanecer no exemplo referido por Jung, nas guerras. Quanto maior o conjunto de explicaçóes que conseguimos amealhar para dar conta das condiçôes de possibilidade de um conflito, tanto menor as condiçốes de precisar, de fato, o que mobiliza tamanho empenho pessoal e coletivo.

Que existam condicionantes históricas, políticas, econômicas, étnicas: cada um desses fatores mostra sua importância na configuração de um conflito, mas nenhum deles, isoladamente, dá conta de explicar a passagem ao ato. Da mesma maneira, somar todos esses fatores e deles simplesmente deduzir a origem de um dado conflito é tornar a guerra um epifenômeno, um fenômeno secundário, derivado, mero acidente de percurso, quase casual. Todavia, “[...] um milhão de zeros colocados em conjunto jamais somarão um.” (JUNG, 1978 b [1957], p. 275).

Na visão de Jung, com base em suas leituras de Eckhart e Goethe, uma apreensão sintética, de conjugação de diferentes fatores criando um novo 
elemento, faz-se necessária para compreender esses fenômenos e o fato psíquico, em geral. Explicaçóes que se valem do formato dadas tais e tais condiçôes, o conflito se tornou inevitável deixariam de lado um fator importante, de ordem afetiva, que permitiria a coesão necessária para sustentar determinada ação, a qual, uma vez lançada, adquire autonomia.

Mudanças decisivas na história são em geral atribuídas exclusivamente a causas externas. Parece-me, entretanto, que as circunstâncias externas frequentemente servem apenas como ocasiôes para que uma nova atitude em relaçáo à vida e ao mundo, por muito tempo preparada no inconsciente, torne-se manifesta. (JUNG, 1981 [1948], p. 314).

Se essa reflexão se aplica sobretudo às atitudes que se sedimentam no convívio humano, criando processos inerciais e padróes de resposta, ela também pode ser pensada no âmbito de movimentos coletivos específicos, tais como a guerra. Para além do fator inercial, Jung insiste no fato de as circunstâncias externas poderem ser pensadas como expressão de complexos afetivos inconscientes que se cristalizam e passam também a ser determinantes da própria configuração das circunstâncias. Independentemente de origem ou prevalência, Jung nos instiga a pensar num funcionamento conjunto entre causas externas e arranjos afetivos, numa espécie de retroalimentação na qual os afetos são moldados por condicionantes externas, as quais, por sua vez, sofrem constantes alteraçôes por força da ação dos afetos. "Condiçóes sociais, políticas e religiosas afetam o inconsciente coletivo no sentido de que todos aqueles fatores suprimidos pelas visóes ou atitudes prevalentes na vida de uma sociedade gradualmente acumulam no inconsciente coletivo e ativam seus conteúdos." (JUNG, 1981 [1948], p. 314).

A respeito de quais conteúdos serão ativados resta uma incógnita. No caso abordado por Jung (1978a [1936]), em Wotan, certo acúmulo de circunstâncias desastrosas acabou por gerar as condiçôes de agenciamento de processos marcadamente destrutivos, articulados através de modelos que emanavam potência, bravura, amor, sabedoria. ${ }^{4}$ Fato é que as açóes coletivas jamais se dão de forma aleatória, nem se podem reduzir a questôes circunstanciais. Embora as circunstâncias sejam o elemento disparador, não

${ }^{4}$ Jung (1936) faz referência a um estudo de Martin Ninck (Wodan und germanischer Schicksalsglaube), no qual Wotan aparece associado a certas figuras, como a do berserker, espécie de guerreiro bárbaro (representação que foi também usada pela revista inglesa Punch, para caricaturar Hitler, após este tomar o poder), deus dos trovóes, do amor (Minne) mágico, deus dos poetas, e também a imagem das Valquírias, uma vez que, acrescenta Jung, fazem parte do pano de fundo do mito. 
só respondem à inércia de processos cumulativos como também reforçam e reatualizam os fatores psíquicos agenciados num dado evento.

Sobre a causa dos acontecimentos históricos, e notadamente da guerra, Tolstói (2017 [1869], p. 947) ainda acrescenta: "A marcha dos acontecimentos do mundo é predeterminada de cima, depende da coincidência de todos os arbítrios das pessoas que participam de tais acontecimentos." O aspecto demoníaco da questão está nessa coincidência de todos os arbítrios, naquilo que coordena as açóes todas, de modo a convertê-las num movimento comum. Um tal aspecto, como ainda lembra o autor, ultrapassa as vontades individuais, as decisôes dos generais, dos ministros, dos reis. Mas que marcha é essa capaz de reunir tantas arbitrariedades circunstanciais e cuja marca distintiva é a do arrebatamento?

Como se frisou acima, não se trata de criar novos psicologismos, mas sim de associar aos fatores antes mencionados também a esfera do psíquico, e mais propriamente, a de um agenciamento inconsciente de processos sociais capaz de acrescentar um fator perturbador, por excelência, no cálculo das condiçóes de um conflito. "A guerra é um comportamento irracional, e não se pode pôr fim a ela por meio da vontade humana." (VALOIS, 1992, p. 264). Assim como não se inicia uma guerra pelo mero acúmulo de condiçóes externas, tampouco se inicia ou se termina um conflito por simples ato de decisão. Jung (1978a [1936], p. 184) insiste nesse ponto, ainda no texto sobre Wotan, ao afirmar:

\footnotetext{
Nós nos convencemos de que o mundo moderno é um mundo sensato, baseando nossa opinião em razoes econômicas, políticas e psicológicas [...]. $\mathrm{Na}$ verdade, eu arrisco a sugestão herética de que a insondável profundeza do caráter de Wotan explica mais do Nacional-Socialismo que todos os três fatores sensatos colocados em conjunto. Não há dúvida de que cada um desses fatores explica um importante aspecto dos acontecimentos na Alemanha, mas Wotan explica ainda mais.
}

A marcha dos acontecimentos veio a operar com e para além dos fatores psicossociais que levaram o nacional-socialismo ao poder, e posteriormente ao delírio coletivo de um Reich de mil anos, sustentado não apenas em políticas econômicas e sociais, mas também no apelo a uma identidade mítica de grande potencial persuasivo. É nisto que se revela a insondável profundeza de Wotan, no fato de as questóes de ordem prática - política, econômica, social, 
até mesmo psicológica - trazerem consigo um motivo que funcionava como liga, como amálgama de uma coerência impossível.

E não precisamos nos deter apenas nesse episódio, já tão descrito e analisado. Se olharmos as guerras atuais, espalhadas por regióes ditas periféricas, a suposta boa-vontade de organismos internacionais é grandemente insuficiente para pôr fim a conflitos que devastam povos e países. Mesmo que nos detenhamos em cálculos mais ou menos conspiratórios, de senhores do mundo sentados confortavelmente a manipular nossas vidas como se mexessem peças num tabuleiro de xadrez, a leitura de Jung nos quer indicar que essa hipótese remota é já consequência de fatores que se mesclam à racionalidade e se apresentam de forma lógica, como explicaçóes razoáveis e bem-encadeadas para acontecimentos cujas condicionantes e consequências escapam às mais rigorosas tentativas de explicação.

Embora possamos acusar certo desgaste nessa dualidade racionalirracional, importante notar que Jung não está propondo uma simples redução à irracionalidade como fator explicativo de conflitos. Ele está apontando para o fato de nossa estrutura racional náo ser autossuficiente e tampouco operar como uma espécie de criação ex nihilo que se autojustificaria. Por mais que acreditemos nisso - e fomos de fato conduzidos a crer nesse "complexo mitológico" (JUNG, 1989 [1938])5 - essa crença, em si-mesma, já denuncia a presença de agenciamentos afetivos no núcleo da razão. Se é possível pensar, de um ponto de vista arquitetônico, uma razão pura, fato é que não existem açóes puras da razão, nem razóes que sejam elas mesmas puras. ${ }^{6}$ Cada um de

${ }_{5}$ No texto A energia psíquica, Jung (2002 [1928], p. 33-34) já afirmava: "No homem civilizado, o racionalismo da consciência, tão útil sob outros aspectos, revela-se um empecilho para a transformação pacífica da energia, pois que a ratio ... aferra-se convulsivamente aos valores por ela uma vez escolhidos, e isto na medida em que a realidade da razão humana é considerada como 'substância imutável', excluindo-se, consequentemente, a sua concepçáo simbolista. Mas a ratio é apenas relativa e anula-se em suas próprias antinomias. Também é ela um meio em ordem a um fim, uma expressão simbólica de uma etapa transitória do desenvolvimento."

${ }^{6}$ Não se trata de questionar a razão enquanto unidade arquitetônica, como sistema que, por sua própria definiçấo, exige que seja pensada enquanto princípio ordenador a priori. "Vê-se pois que o princípio específico da razão em geral (em seu uso lógico) é o de encontrar, para o conhecimento condicionado do entendimento, o incondicionado através do qual a unidade do entendimento é finalizada." (KANT, 2006 [1781], p. 338). É enquanto fundamento estrutural de todo conhecimento, e em seu uso lógico no estabelecimento do princípio incondicionado subjacente às condiçóes do entendimento, que a razão é pura no sentido transcendental, uma vez que as relaçôes todas, sejam da sensibilidade, sejam do entendimento, estão já determinadas por esse princípio ordenador. Ocorre, todavia, que esse princípio está submetido ao corpo, age a partir do corpo, de suas necessidades e carências, quer materiais, quer imateriais. Nesse ponto, a lógica e todo seu aparato são capturados por agenciamentos outros que não os da coerência interna de um sistema. O uso empírico da razão não coincide, pois, com a exposição 
nossos gestos vem marcado pelo estigma do pathos, e a capacidade mesma de apreensão da vida pela via do entendimento é já uma consequência, uma estratégia desenvolvida para fazer frente à nossa subordinação, em maior ou menor grau, à lógica dos afetos.

Discernir uma lógica nos acontecimentos náo implica compreender o próprio pathos epistêmico que nos mobiliza a apreendê-los logicamente, nem o momento em que a lógica passa a nos servir como defesa ou autojustificação. "Fora da matemática que não tem que ver senáo com números mortos e fórmulas vazias, e por isso pode ser perfeitamente lógica, a ciência não é senão um jogo de crianças no crepúsculo, um querer apanhar sombras de aves e parar sombras de ervas ao vento." (PESSOA, 1999, p. 164-165). Mas nada nos impede de sermos imperfeitamente lógicos. Também é verdade que a lógica fria dos números encarna e nos cataloga de várias maneiras: como corpo mudo das estatísticas, um índice a mais nos quadros de violência urbana, ou baixas colaterais de um conflito armado.

Os instrumentais da razão continuam a nos induzir à ideia de que a vida está sob controle, de que é possível acercar-se de dados suficientes para garantir respostas eficazes frente às urgências. Há, com efeito, vários níveis de objetivação, e isso propicia alguma capacidade de manejo das ações no mundo. No entanto, é típico do momento histórico inaugurado com a modernidade derivar disso uma crença racional no controle e na ordem; crença que pode chegar à contradição extrema de tornar-nos fanaticamente racionais - como afirma Hao Wang (1995 [1987]), a propósito de Kurt Gödel.

Pierre Cassou-Noguès (2007, p. 49), também ocupado com a intrincada relação entre loucura e lógica em Gödel, afirma que "[...] nossas crenças, os postulados que determinam nosso mundo, encerram-nos em uma imagem do mundo que pode ser falsa e não obstante insuperável." A história da psicopatologia corrobora as afirmaçóes do autor e nos traz inúmeros exemplos nos quais a razão vacila, tendo como suporte argumentos racionais. E se a razão

de seu princípio formal; e os desafios inerentes à encarnaçẫo da razão estão expostos na antropologia (KANT, 2019 [1798]). Um sistema filosófico cujo núcleo fosse o puro pensamento não poderia sequer ser resultado deste, estritamente falando, visto que o processo de escrever, em si mesmo, é já interrupção e materialização do pensar (ARENDT, 1998 [1958]). Nesse fator prático dos mais diretos, o corpo já mostra sua efetividade. Se somarmos a isso a dimensão dos afetos, das maquinaçốes inconscientes, da disjunção entre afeto e representaçấo, os processos que determinam nossas açốes vão se tornando cada vez mais imbricados. Na vida de Kant, o episódio da Torre de Löbnicht é também um exemplo de como o uso da lógica está relacionado (se não subordinado) aos usos do corpo (DE QUINCEY, 2015 [1854]). 
pode se tornar fanática, de modo a ser arrastada ao que seria supostamente seu contraponto, a loucura, é porque, em sua base, em sua organização mesma, operam também elementos de outra ordem.

Não se trata, aqui, de desprezar esse instrumento que nos permite inclusive criticá-lo, além de ser o grande responsável pelo lugar que acreditamos ocupar na escala da animalidade, embora isso não seja necessariamente um privilégio. A razão é, certamente, um utensílio primordial para nosso agir no mundo, mas há que se abordá-la com a devida cautela, pois ela pode voltar-se contra seus artífices. Acompanhando o pensamento de Jung, compreender que na base da racionalidade atua um intrincado campo de afetos é condição necessária (embora não suficiente) para a responsabilização, apesar do determinismo inconsciente inerente à sua teoria. Nisso se apresenta o que há de propriamente terapêutico, no trabalho de Jung.

Admitir a precariedade estrutural do fundamento racional de nossas açóes é um passo importante para evitar que sejamos capturados pela ânsia de justiça, ou de liberdade, ou de qualquer outra razáo grandiosa invocada para justificar os próprios atos. É preciso compreender o que há de bruto também naqueles que se identificam com ideias mais cosmopolitas, e o quanto estamos, todos, sujeitos a essas capturas que se nos aparecem como perfeitamente lógicas.

Muito estrago tem sido feito em nome da razão, e existe hoje em dia a tendência de associar a razáo com o desejo de preservar a ordem existente (o status quo). Além disso, grandes guerras, uma distribuição mais ampla das informaçóes, e maior liberdade para criticar têm revelado as reais limitações da razão em nosso século. Em função destes e de outros fatos associados, tem ocorrido uma crescente desconfiança em relação à razão e uma concomitante aceitaçáo de múltiplas reduçóes do alcance daquilo que é tomado como sendo o próprio domínio do racional. (WANG, 1995 [1987], p. 225).

Assim é que delimitamos territórios onde imperaria a luminosa organização da razão, e outros nos quais reinaria a barbárie e o nonsense, uma espécie de refugo do processo civilizatório. Se a abstração chamada comunidade internacional seria o lócus por excelência daquilo que se usa representar como valores mais altos da humanidade, tudo que permanece à margem disso é mais ou menos escuridão, influência, forças fora de controle, as quais, no limite, culminam na ideia de terror. Os elos intermediários entre o suposto 
nonsense e a pretensa organização racional dos afetos passam despercebidos, ou amortecidos pela "distribuição mais ampla das informaçóes", considerando ainda que essa distribuição nada tem de ingênua.

Não deixa de causar espanto, por exemplo, o quanto se está sujeito a atos gratuitos de violência, os quais escapam às delimitaçôes frágeis da ordem social estabelecida, apresentando-se como rupturas abruptas, desproporcionais ou simplesmente sem sentido. Perpetua-se, assim, o caráter demoníaco num mundo esvaziado de demônios. Quanto mais se admiram os frutos da razão, menor a disposição para observar o bagaço que alimenta o fogo do esclarecimento. E mesmo o discernimento de processos macro e geopolíticos serve antes para distribuir a angústia causada pelas irrupçóes de violência do que para construir soluçóes de fato.

O que assombra é a compreensão difusa de não haver solução possível; que os múltiplos desarrazoados do mundo são inerentes à própria arquitetura da vida e que nossos cálculos estáo todos fadados a se mostrarem falsos ou limitados, mais dia, menos dia. Essa autonomia dos processos vitais, na qual estáo inclusos os variados comércios de morte, engendra respostas também em grande medida autônomas, no sentido de as razóes suscitadas serem mobilizadas por um amplo espectro de afetos: do medo à ganância, passando pelo amor, por vezes tão cruel quanto o ódio.

O inferno são os outros; ou, mais propriamente, a forma como nos relacionamos com os outros (SARTRE, 2004). E se é possível certa dose de liberdade para transformar os agenciamentos que nos ligam uns aos outros, essa relação inevitável não cessa jamais de ser inquietante, uma vez que nos lembra a precariedade da condição humana e quanto, para além de toda boa vontade e sinceridade, estamos sujeitos a ser arrastados ao ódio ou à indiferença. $\mathrm{O}$ inferno é também a compreensão difusa de que, no âmago das intençôes, há mais do que as razóes confessadas, ou as que conseguimos inventar. De boas intençốes o inferno está cheio, diz o dito popular.

Sempre o demoníaco voltando à superfície, seja na banalidade dos gestos cotidianos, seja nos atos mais trágicos do mundo. Nesse sentido, podemos ver na guerra o despertar de um coeficiente latente de ódio e destruição, elevado “[...] à potência de psicose coletiva”, como escreveu Einstein, em carta a Freud, no ano de 1932 (EINSTEIN; FREUD, 1996 [1933], p. 195). Diferentemente de Arthur Schnitzler, que atribuía a guerra a "intençôes pérfidas de um pequeno grupo de indivíduos que lucram” com ela (ELLENBERGER, 1994 
[1970], p. 499), a psicanálise opera no registro de forças agressivas, pulsão de morte, compulsão à repetição, que Freud diz ter "[...] a aparência de uma força demoníaca [d̈̈monischen Charakter]" (1996 [1920], p. 46), criando a sensação de se estar movido por um destino.

A partir de premissas distintas das utilizadas por Freud, Jung vai situar a guerra em termos de epidemia psíquica: "A qualquer momento, milhôes de pessoas podem ser afetadas por uma nova loucura, e neste caso deveremos ter outra guerra mundial ou revolução devastadora.” (1991 [1932], p. 177). Estão implícitas nessa leitura a ideia de contágio e a autonomia dos fatos psíquicos. Em maior ou menor grau - e quanto mais imersa no coletivo é a pessoa, mais isso se faria evidente -, estamos todos submetidos a uma dinâmica coletiva que nos move e, por vezes, nos solapa. Essa dinâmica coletiva é, por sua vez e a um só tempo, mobilizadora de e movida por forças elementares de nossa própria psique. Se o homem conseguiu controlar, em grande medida, as forças da natureza, o mesmo não se dá com a vida psíquica. "A era da razão, que despojou dos deuses tanto a natureza quanto as instituiçóes humanas, negligenciou o Deus do terror que habita a alma humana." (JUNG, 1991 [1932], p. 177).

Esse Deus do terror se apresenta nas muitas formas de violência que experimentamos e com as quais até mesmo flertamos, pois, se nos causa algum choque ver um atentado a bomba, numa capital do mundo ocidental, estamos menos susceptíveis a nos compadecer com mortes que se dão em países árabes e quase que imunizados contra a violência cotidiana das grandes cidades brasileiras. Aliamo-nos a franceses e britânicos, expressamos um ou outro lamento diplomático por um ataque aéreo em Aleppo, ${ }^{7}$ e quase não nos damos conta da violência implicada no fato de se ter, no Brasil, crianças pedindo dinheiro em semáforos, sendo excluídas sistematicamente da possibilidade de integrar de modo mais autônomo o palco do mundo, sujeitas que estão a condiçôes precárias ou inexistentes de educação e saúde públicas.

O quadro de protoguerra urbana, em algumas de nossas cidades, entra num circuito distinto, no qual operam questôes de classe social, étnicas, político-ideológicas, e a própria distribuição dos territórios urbanos, com os

7 Amin Maalouf (1998, p. 87) alude a essa assimetria nos seguintes termos: "Ao Sul e à Leste do Mediterrâneo, encontramos milhōes de pessoas capazes de falar o inglês, o francês, o espanhol, o italiano. Do outro lado, quantos ingleses, franceses, espanhóis, italianos, julgaram útil estudar o árabe ou o turco?" Isso ultrapassa questóes mais objetivas da colonização para inserir no problema a discussão da lógica dos afetos nos traços identitários. 
diversos níveis de violência a ela atrelados (SANTOS, 2001 [2000]). ${ }^{8}$ Uma mesma pessoa que sofre pelos efeitos devastadores de ataques a bombas na Europa é capaz de estar imunizada em relação ao terror cotidiano de nossas cidades, sobretudo quando as baixas desse conflito permanente se dão à distância dos olhos, ou nos chegam amortecidas pelo filtro da mídia, a qual opera ativamente na oferta de laços identitários e na fabricação dos fatos sociais. Isso nos mostra novamente como a lógica pode ser falseada, quando os afetos estáo em jogo, e que a lógica dos afetos nos leva a comportamentos paradoxais, ou francamente contraditórios.

Se forças elementares da psique são capazes de mobilizar afetos coletivos é porque a capacidade de domínio sobre essa dimensão de nosso funcionamento é precária, o que nos deixa à mercê de situaçóes tanto mais absurdas quanto aparentemente anacrônicas. Nesse sentido, o Direito Internacional Humanitário, fixado pelas convençôes de Genebra após a guerra de 1939 a 1945, destinado a dar um escopo racional aos conflitos armados (visando notadamente a regulamentar e a proteger prisioneiros e população civil não envolvida nos conflitos), mostra toda sua fragilidade, e mesmo sua impotência, a cada vez que um novo conflito emerge.

Essa tentativa de colocar ordem na desrazão - cujo objetivo final e não declarado é nos aliar afetivamente à crença humanista de que é possível chegar ao controle da vida, através da razão e do bom-senso - está condenada de antemão ao fracasso. Ela só faz reforçar o fato de que os ordenamentos dos contratos sociais podem ser suspensos, se uma necessidade considerada imperiosa se apresenta.

Existem estruturas dinâmicas inconscientes que sáo anteriores a toda tomada de posição da vontade e que se impóem a ela sem que a vontade possa modificá-las de forma alguma: quando muito, a vontade pode lhes fazer obstáculo, opondo-lhes a resistência do recalque ou da repressão, mas sem que consiga, com isso, reduzir a nada tais estruturas. (VALOIS, 1992, p. 270).

\footnotetext{
${ }^{8}$ A instrumentalização do território pelo poder econômico e político, argumenta Milton Santos (2014 [1987], p. 134), faz com que este se torne "[...] causa de maior desigualdade entre firmas, instituiçóes e sobretudo entre homens. Em lugar de se tornar o desejado instrumento de igualdade individual e de fortalecimento da cidadania, o território manterá seu papel atualmente perverso, náo apenas alojando, mas na verdade criando cidadáos desiguais, não apenas pelo seu lugar na produçấo, mas também em função do lugar onde vivem."
} 
Ao menos no curto prazo, conflitos arraigados ao longo do tempo são dificilmente demovidos, ainda que o desfecho não seja necessariamente a guerra. Também é notório o potencial de repetição que desafetos de longa data podem gerar, embora permaneçam por largos períodos em estado de latência. Uma vez mais, estamos no âmbito do demoníaco, no sentido de que a irrupçáo de um conflito nos ultrapassa, bem como às decisóes de cada qual.

Quanto à constituição do sujeito, em sua intransferível singularidade, a mesma estrutura se aplica: assim como não se tem o domínio das forças coletivas que operam na configuração de um conflito, tampouco somos senhores de nossa própria vida - como noutros termos já o alertara Freud -, e somente a duras penas conseguimos nos arrancar das vicissitudes que nos constituem, para erigir um núcleo de pessoalidade. Isso é evidente nos horizontes mais diversos. Desde a língua na qual constituímos nossa capacidade de expressão até as variadas determinaçóes genéticas a que estamos sujeitos, a vida de cada qual acontece fundamentalmente à revelia das próprias decisôes.

A tragédia humana se faz nesse embate entre razão e imponderável, na interseção entre coletivo e singular, e não é de estranhar estarmos sujeitos ao sintoma, à loucura, a psicoses coletivas. É bem verdade que há gestos os quais proporcionam a impressão de um não sei quê de humanidade, um sentimento também difuso de preservação da vida, mas que é, no fundo, resultante de alguma crença. Nisso também se apresenta o aspecto enigmático do fundo afetivo que alimenta relaçóes e escolhas. "A ideia de que algo que não venha de fora possa ser real ou verdadeiro mal começou a despontar no homem contemporâneo" (1978a [1936], p. 185), escreve Jung, em seu ensaio sobre Wotan, salientando o quanto estamos despreparados para o confronto com esse coeficiente pulsional que mobiliza estratos mais recônditos da psique. $\mathrm{Ou}$, como assinala Nietzsche (1999 [1873], p. 54): O homem repousa, a despeito de seu não-saber, sobre um fundo impiedoso, insaciável, mortífero, e como que pendente em sonhos sobre o dorso de um tigre."

Como sustentar, a partir disso, o valor da vida? Em Nietzsche, a resposta passa pelo amor fati, contraponto e superaçáo do niilismo. O niilismo, como incapacidade de acreditar, está, paradoxalmente, na base de todo o idealismo 
e, por conseguinte, de toda crença (CAMUS, 1954 [1951]). Esse espírito de negação se manifestaria não somente no ateísmo, no utilitarismo, nas apologias à destruição, mas também em certo semblante de afirmação; na construção de ideais aparentemente afirmativos, mas que estariam secretamente a serviço da negação do mundo.

Ainda antes de Nietzsche, Turgueniev apontara a relação entre um mundo que entrava em decadência e seu contraponto no espírito de negação, o qual, todavia, assumindo o caráter de uma espécie de doutrina do negativo, acabava por se tornar também um refúgio. A própria negação dos valores todos acabava sendo uma espécie de construção de ideal: "[...] o niilismo deve auxiliar-nos em todas as desgraças" (TURGUENIEV, 1984 [1862], p. 49), ironiza o aristocrata Pàviel Pietròvich, um representante do mundo decadente que se tratava de negar.

A negação absoluta é, como sustenta Camus, na esteira de Nietzsche, um estado patológico, que distorce, em maior ou menor grau, toda possibilidade de convívio. Ela resultaria na aniquilação ou no ideal, e cada um desses extremos de expressão do negativo seria também uma maneira de recusar o amor ao que está dado, da forma como está dado.

O problema do valor da vida se articula a cada uma das esferas da ação humana e, se um talento do niilismo está na denúncia da parcialidade e fracasso essencial de todo julgamento, o próprio niilismo é também valoração. ${ }^{9}$ E se um vigor do niilismo está no apontar o fato de que derivamos seguidamente para ações cuja fonte é o ressentimento ou o desejo de vingança, o próprio niilismo é também uma recusa, um deixar cair os braços ao sol-pôr do esforço. Está na raiz do niilismo uma atitude que oscila entre o pessimismo e o otimismo (NIETZSCHE, 1987 [1888]), ${ }^{10}$ ambos resultando em visôes distorcidas, ou mesmo retorcidas do mundo. E se o pessimismo pode render figuras mais grotescas e violentas, imagens de aniquilação e desordem, o otimismo é talvez a expressão mais insidiosa do niilismo, uma vez que recobre a cara feia do mundo com um véu de esperança.

\footnotetext{
9 Particularmente, o problema da "convicção": "O filósofo niilista é um convicto de que tudo o que acontece é desprovido de sentido e feito em vão; não deveria, porém, existir o ser inútil e desprovido de sentido. [...] O niilista, em resumo, significa que o olhar volvido para semelhante ser vazio e inútil absolutamente não satisfaz ao filósofo, causando-lhe impressão de vazio e desolação.” (NIETZSCHE, s/d [1901], p. 98).

10 "A 'preponderância da tristeza sobre a alegria' ou então o contrário (hedonismo): estas duas doutrinas já são indícios do niilismo.” (NIETZSCHE, s/d [1901], p. 98).
} 
É obra do espírito do pesadume fazer com que a inteligência minta acerca do coração, e, se essa mentira pode expressar-se de modo rancoroso, pode também ser alegre e fagueira. $\mathrm{O}$ desejo de engano é sutil, e tanto mais ardiloso, se se acostuma a enxergá-lo apenas de fora, criticamente, como se estivéssemos, pela própria capacidade crítica, isentos de sofrer os achaques da ilusão. Isso, todavia, seria desconsiderar o aspecto demoníaco que envolve e alimenta todos os agenciamentos afetivos mobilizados pela vida, em sua potência e em suas precariedades. Não se pode evitar os demônios por longo tempo, sem que paguemos um preço por isso: "Não poucos, que queriam expulsar os demônios, se meteram com os porcos." (NIETZSCHE, s/d [1885] p. 57).

No entanto, se o espirito do pesadume pode adquirir contornos táo diversos, de que formas ele se acercaria de nós, brasileiros? Que estratégias nossa inteligência criou para furtar-se ao coração? Ademais, o que se esconde por debaixo da tão alardeada alegria tropical dos brasileiros? Que demônios alimentamos, nos ermos da brasilidade? Não é certo que a pretensa alegria dos brasileiros seja um fato necessariamente benfazejo, e também cabe indagar se nosso temperamento seria de fato "[...] ordeiro e pacífico de seu natural" (ANDRADE, 1996 [1928], p. 81) - imagens com as quais nos acostumamos, as quais se naturalizam à medida que nos são transmitidas como amálgama de uma incerta ficção de brasilidade, e retornam à praça pública como reflexos de um impreciso espirito coletivo.

Acaba-se até mesmo por nutrir alguma simpatia por essa imagem da alegria, ao tempo em que nos munimos de desconfiança quanto a outras análises de inspiração mais generalizante. Todavia, se se pode tomar esses traços gerais da alegria e da "lhaneza no trato" (HOLANDA, 2014 [1936], p. 176) como elementos que nos espelhariam em certa medida, cabe também indagar seus concorrentes. Que implicaçóes o gosto de mando, a cordialidade e o que poderíamos chamar de um fator Macunaima geram, em nossa cultura? Como pensar nos desdobramentos, na inércia que esses caracteres, embora fictícios, produzem em nosso modo coletivo de viver?

Milton Santos (2014 [1987]) compreende que “[...] não há povos desonestos por índole", e afirma: "A ideia de que cada um de nós é, sempre, um faltoso efetivo ou potencial, permanece na vida diária dos trabalhadores, menos por vício original da raça e mais pela falta de medidas do poder público que erijam a credibilidade em uma norma, a começar pela própria credibilidade do governo." (p. 34). Ocorre, no entanto, que normas e credibilidade de 
governos também possuem uma face de caricatura de operaçóes coletivas. De outro modo, escorregamos sutilmente para uma ideia - náo totalmente desprovida de sentido, mas ainda assim secundária - de que um punhado de agentes mais ou menos desonestos contribuiriam para instigar a transgressão. Que isso ocorra, efetivamente, não impede que analisemos esse fato também sob a perspectiva de um precipitado coletivo que se encarna nas leis, no cumprimento destas, nas figuras eleitas para exercer cargos públicos e, por fim, nas relaçốes cotidianas.

Toda ação coletiva, arraigada no transcorrer do tempo histórico de um povo, produz traços, produz inércia, como qualquer corpo. Essa inércia, se não responde pela totalidade das açôes levadas a cabo num dado grupo de pessoas, ou mesmo em cada uma das pessoas que compóe um grupo, dá conta de certa inspiração coletiva, de automatismos que se instalam no corpo da cultura, e que, na dinâmica das trocas, acabam por ser também constitutivas da cultura, como se realçou acima. Da dificuldade em pronunciar alguns fonemas no aprendizado de línguas ao potencial agressivo das palavras, passando ainda pelos sotaques específicos de cada linguajar, a linguagem modula o corpo, dobra-o literalmente. Da linguagem às mitologias cósmicas, a cultura encarna.

Se é ingênuo acreditar - como a psicologia profunda já o demonstra, no mínimo, desde Nietzsche - que nossas açôes são resultantes diretas de escolhas conscientes, também é ingênuo supor que essas mesmas ações não tragam consigo ecos de inúmeros agenciamentos coletivos, dos romances familiares aos mitos. Caio Prado Júnior (2011 [1942]), por exemplo, afirma que é preciso considerar os efeitos do trabalho servil, levando-se em conta a proporçáo que atingiu, em nossas terras, na organização econômica, nos padrôes materiais e morais. "Nada há que a presença do trabalho servil ... deixe de atingir; e de um modo profundo, seja diretamente, seja por suas repercussóes remotas." (PRADO JÚNIOR, 2011 [1942], p. 285).

São justamente essas repercussões remotas que é preciso incluir nestas reflexôes, porque elas sedimentam tonalidades afetivas em nossa cultura, bem como em nossos corpos. Retomando aqui o que assevera Jung (1978a [1936]) a respeito de Wotan, precipitados culturais vão se acumulando e podem "possuir" uma coletividade como forma de reação à recusa desses traços. Se essa marca do trabalho servil possui uma dinâmica interna, e se ela age profundamente em nós, como isso se expressa, no cotidiano? $\mathrm{O}$ gosto de mando, ao qual Gilberto Freyre (2006 [1933]) faz referência, em Casagrande e senzala, poderia aqui ser visto como expressão de traços residuais que 
se perpetuam para além do instituído. Se já nos livramos formalmente do trabalho escravo, suas marcas não necessariamente se apagaram da cultura, nos mais variados horizontes de nosso modo de viver. $\mathrm{O}$ autoritarismo é um deles.

Por mais difícil que seja pensar em traços coletivos, sobretudo se considerarmos a inalienável singularidade no modo como cada qual se apropria e é apropriado por traços de cultura, poder interrogar esse fator é de fundamental importância. Esse olhar sintético que busca padróes de maneira alguma exclui (nem impede e mesmo demanda) um olhar para a singularidade. Numa análise da obra Psicologia do povo brasileiro, Eduardo Diatahy de Menezes (1998, p. 27) lembra uma advertência que o próprio Tristão de Athayde faz sobre as dificuldades de compreender traços gerais da brasilidade:

Antes de propor a caracterização dos traços que formam a unidade de nosso povo, seria prudente indicar as grandes linhas de demarcação da nossa variedade psicológica, pois a rigor, para ser fiel a tal variedade de tipos, terse-ia de descer a cada homem em particular, visto que não há duas criaturas humanas rigorosamente iguais, nem fisica nem psicologicamente.

Inspirado pela psicologia dos povos, Tristão de Athayde acaba por ceder a uma tipologia tanto mais fantasiosa que grandemente detalhada, eivada de estereótipos impressionistas, como afirma ainda Eduardo Diatahy de Menezes. Mais do que a expressão de traços de um povo, o trabalho de Athayde seria "[...] indicador do estilo cognitivo de uma época de nossa tradiçấo letrada, sem rigor analítico e polarizado pelo pitoresco ou o exótico." (MENEZES, 1998, p. 33).

Somado a esse gosto pelo exótico, transparece aqui o perigo que representa o recurso a tipologias (amplamente utilizado por Gilberto Freyre). ${ }^{11}$ Cabe pensar, todavia, se para além desses problemas não seria possível uma abordagem em termos gerais, sem se deixar tragar por reducionismos demasiadamente grosseiros. Noutros termos, trata-se de buscar tonalidades de fundo da brasilidade, sem que isso signifique descuidar dos limites de uma tal atitude, limites condicionados pela exuberância dos agenciamentos pessoais, familiares, comunitários, regionais. "Explicações semelhantes são exatas apenas na medida em que patenteiam o que há de excêntrico e mais

\footnotetext{
${ }^{11}$ Assim como o conceito de eugenia, o que mostra não somente quão arraigados são os estereótipos impressionistas, mas também o quanto eles se podem apoiar em cientificismos, para fins de autojustificação.
} 
ostentoso na verdade: realismo do traço grosso e da caricatura." (HOLANDA, 2014 [1936], p. 70).

É justamente disso que se trata, do traço grosso e da caricatura, os quais revelam ao exagerar, que exageram para melhor chamar atenção ao que está velado nos usos do cotidiano. O "mandonismo dos proprietários de terras e escravos" e os "abusos e violências dos autocratas das casas-grandes" (FREYRE, 2006 [1933], p. 324) geraram, ressalta ainda Gilberto Freyre, um gosto de mando que se exerce tanto na esfera privada quanto "[...] no exercício de posição elevada, política ou de administração pública." (FREYRE, 2006 [1933], p. 114). Isso é algo que se pode ver cotidianamente no Brasil. Mesmo que suspendamos o elo causal, não é difícil notar que nossa estrutura social transpira o autoritarismo, e também o compadrio. ${ }^{12}$ Essa característica, por sua vez, nos aproxima do que Sérgio Buarque de Holanda trabalha como cordialidade, ou seja, relaçóes que se instituem a partir da lógica do íntimo, do familiar, que não são necessariamente amistosas, e se estendem à esfera pública, a partir da lógica do privado.

A "riqueza adquirida sem trabalho" (FREYRE, 2006 [1933], p. 403), igualmente característica do regime escravocrata, é outro elemento que concorre para o gosto de mando, no sentido de aproximar os pares, os detentores do poder econômico e político, gerando pouco a pouco uma dinâmica de retroalimentação, a qual, como nossa realidade atual revela de modo cru, em nada perdeu seu vigor nas instituiçôes políticas nacionais. Esse oportunismo não se aplica apenas às velhas oligarquias ciosas de perpetuar seu poder econômico e sua influência política, mas também a novas geraçóes que acabam por reproduzir esse traço, mesmo náo pertencendo a castas tidas por tradicionais. Isso, por sua vez, remete-nos ao caráter de contágio e de reproduçáo mais ou menos inconsciente de padrôes de funcionamento; noutros termos, remete-nos ao demoníaco que opera nos interstícios das relaçóes sociais.

Esse modo de operação se espalha, da mesma forma, no convívio mais banal da vida cotidiana, enraíza-se, ganha contornos de uma quasenaturalidade. Do tão difundido clichê você-sabe-com-quem-está-falando à perpetuação de regimes de trabalho análogos à escravidão, além da contumaz

\footnotetext{
12 "A casa-grande, completada pela senzala, representa todo um sistema econômico, social, político: de produção (a monocultura latifundiária); de trabalho (a escravidão); de transporte [...]; de religião [...]; de vida sexual e de família (o patriarcalismo polígamo); de higiene do corpo e da casa [...]; de política (o compadrismo)." (FREYRE, 2006 [1933], p. 36).
} 
dificuldade (deliberada ou não) de se seguir normas, muitos gestos do cotidiano denotam ao menos um gosto pela autoridade, embora fictícia, mesmo que meramente ambicionada. Este é um ambiente propício para se exercer um gosto de mando violento ou perverso (FREYRE, 2006 [1933]).

Pode-se optar por não dar conta desse padrão de funcionamento, ou sequer ver nisso um traço; acreditar que se trata de manipulação midiática, fabricação. Pode-se, por outro lado, tratar desses recortes como apresentação de determinadas configuraçôes afetivas, e buscar através deles uma apreensão de conjunto, mais abrangente. Ser uma fabricação manipulada não implica deixar de ser parte da expressão de uma dada configuração afetiva. De outra maneira, dificilmente esses modos de agir encontrariam ressonância nas pessoas. Ao abordar a figura do Trickster, espécie de demônio arteiro e trapaceiro dalgumas mitologias, Jung (1990 [1954], p. 270) afirma que, em geral, a autonomia da figura mitológica resulta do fato de ela "[...] secretamente participar da psique do observador e aparecer como uma espécie de reflexo, embora não seja reconhecida como tal." Isso se aplica aos mitos, no que eles provocam uma estranha familiaridade, mas também aos construtos sociais, os quais possuem um aspecto autônomo e se perpetuam, ao refletir certa sintonia com modos de ser de uma coletividade.

Nutrir um gosto de mando não se opõe necessariamente à cordialidade, especialmente quando se está do lado de quem manda. A cordialidade tampouco significa amizade ou honestidade, e sim a ideia de que as açôes são marcadas por tonalidades afetivas que tendem à exuberância, e seguidamente ao exagero, numa filosofia que oscila entre "[...] otimismo ao excesso e pessimismo ao excesso.” (ANDRADE, 1996 [1928], p. 459). O gosto de mando pode conviver com e ser mesmo dirigido ao próprio grupo primário donde se origina (HOLANDA, 2014 [1936]). A psicologia profunda é hábil em decodificar as formas como a tirania pode ser exercida sob escusas de amor, ou como se pode ser cruel e mesquinho, através de gestos perfeitamente institucionalizados.

Essa descrição do comportamento autoritário se aproxima de um funcionamento humano tão geral, que poderíamos suspeitar da precisão em torná-lo traço típico nalguma definição de brasilidade. Contudo, como toda produção cultural é encarnada de formas distintas em diferentes pessoas, traços de ordem mais geral podem bem ser dobrados à moda da casa. A questáo entáo se inverte: o ponto nodal é compreender como a brasilidade se constitui, em 
função de padrôes tão amplos, ao mesmo tempo que os remodela, trazendo a eles matizes que passam a ser identificados como típicos.

Nesse sentido, até mesmo as categorias de análise sociológicas forjadas para se pensar a brasilidade compóem a caricatura daquilo que nos tornamos, a partir de padróes de funcionamento que de modo algum são peculiaridades brasileiras. Assim é que o autoritarismo, no Brasil, torna-se gosto de mando na leitura de Gilberto Freyre, o que traz já na própria definição o aspecto afetivo, passional, em oposição ao caráter frio e calculado que o autoritarismo atingiu na Europa da primeira metade do século XX. ${ }^{13} \mathrm{O}$ gosto de mando, somado à cordialidade, se expressa no "[...] desconhecimento de qualquer forma de convívio que não seja ditada por uma ética de fundo emotivo" (HOLANDA, 2014 [1936], p. 178), o que pode ser ainda potencialmente desastroso, sobretudo se pensarmos em termos de acolhimento de padróes gerais de convívio.

Mesmo que não seja tão radical, esse fundo emotivo se mostra de maneira contundente, e tem na ideia de alegria e hospitalidade dos brasileiros dois de seus maiores porta-vozes. Entretanto, se, por um lado, essas qualidades nos positivam, por outro, podemos pensar que mascaram as paixóes tristes marcadas em nossa carne pela servidão, o que resulta em diferentes graus de ressentimento e em distintas tonalidades de violência. $\mathrm{O}$ imperativo da alegria como niilismo, como negação dessas paixôes acabrunhadas.

Aqui se poderia introduzir o fator Macunaima como uma espécie de demônio, um trickster, ${ }^{14}$ na medida em que evoca processos autônomos e nos lança numa espécie de jogo de espelhos, no qual muitas de nossas atitudes cotidianas são reproduzidas na forma já mencionada da caricatura. Há nesse

\footnotetext{
${ }^{13}$ Jean-François Steiner (1976 [1966]) aborda o caráter técnico e meticuloso adotado por Kurt Franz, último comandante do campo de extermínio de Treblinka, no que o autor denomina "sistema Lalke" de operacionalização da solução final. Apesar das muitas controvérsias em torno dessa obra de Steiner, no que diz respeito ao aspecto sistemático e técnico da operação nazista, nos campos de extermínio, concordam também Hannah Arendt (1999 [1964]) e Primo Levi (2015).

${ }^{14}$ Existem já alguns estudos fazendo associação entre as figuras de Macunaíma e do trickster, como o de Carvalho (1997) e Amado (2015). Mais do que reduzir uma figura a outra, ou pretender sintetizar toda a problemática em personagens míticos, trata-se de aproveitar as continuidades e possibilidades explicativas das aproximações, sem desconsiderar as descontinuidades e distanciamentos.
} 
personagem algo de uma leviandade trágica e de um idealismo desprovido de lastro. Não se sustenta a ausência de caráter impunemente, e o final da saga de Macunaíma é tão desastroso quanto patético, no sentido de que há ali um pathos indomável e um panorama de fundo que é, não obstante seu aspecto gozado, trágico e triste. ${ }^{15}$

Em carta a Sousa da Silveira, de 26/04/1935, Mario de Andrade (1968, p. 165), apresentando a ideia de seu Macunaíma, afirma que “[...] inumeráveis brasileiros o xingam de livro porco." Se isso pode ser tomado pela via da forma, pelo estardalhaço que Macunaíma causou na crítica de época, pode-se também considerar essa repulsa pelo viés do potencial de ressonância do personagem. Desta feita, a familiaridade com a caricatura ali delineada nos causaria desconforto e recusa, assim como pregadores militantes do moralismo estáo muitas vezes lutando contra os próprios demônios.

A persistência de aspectos míticos em sociedades ditas civilizadas é, para Jung (1990 [1954]), uma demonstração de que a influência de complexos afetivos permanece inalterada na psique, ainda que as imagens se convertam e se atualizem, de modo a permitir sua expressão num mundo desencantado. "Aqui o trickster é representado pelas contra-tendências no inconsciente, e em certos casos por uma espécie de segunda personalidade, de um caráter pueril e inferior." (JUNG, (1990 [1954], p. 262). Seguindo essa via, Macunaíma apareceria de fato como um trickster, um psicologema que ressoa no fundo da brasilidade e faz com que nos reconheçamos estranhamente naquela figura de um heroísmo pueril, vencido pelo despropositado de suas açóes.

Há algo em Macunaíma que trata de um subsolo de nosso processo cultural, de nossa estruturação enquanto povo brasileiro. Um contraponto ao esforço civilizatório, criativo e ao mesmo tempo destruidor, o qual reuniu à força povos distintos, cada qual com sua longa trajetória, seus fantasmas e suas aspiraçóes. Enquanto figura destinada a ser uma espécie de síntese, de fusão brasileira (ANDRADE, 1968), evocando “[...] valores étnicos ou puramente

\footnotetext{
${ }^{15}$ Numa carta a Álvaro Lins (04/07/1942), Mario de Andrade (1996 [1928]) expressou seu desgosto com o destino de Macunaíma: "Mas a verdade é que eu fracassei. Si o livro é todo ele uma sátira, um não conformismo revoltado sobre o que é, o que eu sinto e vejo que é o brasileiro, o aspecto 'gozado' prevaleceu. É certo que eu fracassei." (p. 515). Também em carta a Fernando Sabino (16/02/1942), Mario de Andrade se queixa da recepção que teve seu livro: "Mas os pouquíssimos que refletiram sobre o livro: ou foram uns porque-me-ufano-do-meu-país que recusaram a sátira e continuaram muito satisfeitos da vida, ou foram os que só retiraram do livro um reforço consciente de seu amoralismo... nacional.” (p. 514). Depois ainda segue dizendo que Macunaíma é uma obra-prima que falhou. A discussão de Jung sobre Wotan e trickster ressoa nesse mal-estar de Mário de Andrade.
} 
circunstanciais de raça" (ANDRADE, 1996 [1928], p. 495), há em Macunaíma uma vibratilidade vital que nos convoca à identificação, seja pela repulsa, seja pela admiração. A questão a se avançar aqui é que o "circunstancial" também cria raízes, naturaliza-se e pega-se à pele como tatuagem. A força inercial dos gestos coletivos cria pouco a pouco as condiçóes para que um dinamismo autônomo se configure e siga nos assombrando, mesmo quando aparentemente superamos nossas condiçôes iniciais. Assim é que a ausência de caráter sobrevive às instituiçóes, o gosto de mando se perpetua para além do regime escravocrata e a cordialidade, investida bem ou mal na ideia de uma compulsão à alegria, protege do aspecto desolador que existe na interseção de todas essas características.

Se todo niilismo tem como base uma negaçáo, talvez o que mais caracterize nossa forma de fugir às mazelas da brasilidade seja o imperativo da alegria. A negaçáo da tristeza pela via de certo semblante de alegria e de bem viver. Uma figura desse paradoxo é a capacidade de verter o espírito do pesadume na leveza d'um samba. Um niilismo tropical.

O propriamente demoníaco dessas categorizaçóes está no fato de que, mesmo se todas elas forem tortas ou forjadas, isso não impede que a marcha dos acontecimentos ganhe um contorno que permita inclusive a invenção dessas categorias de análise. E mesmo que sejam falsas, isso não evita que fatos se reeditem, e que tais categorias ressurjam como caricaturas pegadas à cara das gentes, realimentando traços que vão pouco a pouco ganhando autonomia nas formas de apresentar e vivenciar a nebulosa da brasilidade.

Se Wotan permaneceu como negativo latente da cultura germânica, forçando gradativamente a saída de seu estado de hibernação e carregando consigo todo um povo, também Macunaíma latejaria nas veias da brasilidade? Talvez ele se mostre com tal crueza em nosso cotidiano, que quase não chegamos a nos reconhecer, embora, no fundo, para além das justificaçóes e das expressóes escandalizadas, reste a suspeita de que o gesto de desleixo ou aquele outro de malandragem possam ser lidos como ecos de um demônio familiar.

Nada disso impede que esses agenciamentos sejam também fontes de criatividade, e nossa cultura o demonstra, até mesmo na estética da miséria que faz da esperteza uma necessidade. No entanto, é próprio do trickster, igualmente, rir a bandeiras despregadas, e cabe avaliar que tipo de trapaça se esconde por detrás da graça, e o custo que o imperativo da alegria nos tem 
gerado: nossas dissonâncias tropicais entre a abundância e a escassez; entre a leveza desatenta e o pesadume sorridente; entre os apelos ao sublime e os flertes com o grotesco.

GEWEHR, R. B. Demons of brazilianness: notes for a tropical nihilism. Trans/form/ação, Marília, v. 44, n. 3, p. 343-370, Jul./Set., 2021.

\begin{abstract}
This essay aims to establish some keynotes for an inquiry about the possibility of a "brazilianness", taking nihilism as a central analytical concept. Is it possible to think of a specific operation with this concept in our particular context? The idea of a demoniac turned out to be important to approach the share of the undetermined that remains in every collective construct. Psychic dynamics, whether individual or collective, always evolve in the culture on overdetermined forms. Trying to think of this "brazilianness", and considering the overdetermination of cultural and psychic facts, we propose to intertwine nihilism and some Brazilian cultural traits already studied by authors such as Mario de Andrade, Gilberto Freyre, Sérgio Buarque de Holanda.
\end{abstract}

Keywords: Nihilism. Brazilianness. Cultural traits.

\title{
REFERÊNCIAS
}

AMADO, R. Macunaíma, um trickster. Cadernos do CNFL, v. 19, n. 8, p. 243-263, 2015.

ANDRADE, M. Cartas a Alceu, Meyer e outros. Rio de Janeiro: Editora do Autor, 1968.

ANDRADE, M. (1928). Macunaíma - O herói sem nenhum caráter. Rio de Janeiro: UFRJ Editora, 1996.

ANJOS, A. dos (1912). Eu e outras poesias. São Paulo: Martin Claret, 2001.

ARENDT, H. (1958). The Human Condition. Chicago: Chicago University Press, 1998.

ARENDT, H. (1964). Eichmann em Jerusalém. São Paulo: Companhia das Letras, 1999.

ASSIS, M. de. A estátua de José de Alencar. In: ASSIS, M. de. Páginas recolhidas. Rio de Janeiro: Garnier, 1906.

CAMUS, A. (1951). L’homme revolté. Paris: Gallimard, 1954.

CARVALHO, S. M. S. Macunaíma, Maíra e Quarup. Itinerários, 11, p. 55-80, 1997. 
CASSOU-NOGUÈS, P. Les démons de Gödel: logique et folie. Paris: Seuil, 2007.

DE QUINCEY, T. (1854). The Last Days of Immanuel Kant. Adelaide: The University of Adelaide Library, 2015.

EINSTEIN, A.; FREUD, S. (1933). Por que a guerra? Rio de Janeiro: Imago, 1996. (Volume XXII da Edição Standard das Obras Completas de Sigmund Freud)

ELLENBERGER, H. (1970). Histoire de la découverte de l'inconscient. Paris: Fayard, 1994.

FREUD, S. (1920). Além do princípio de prazer. Rio de Janeiro: Imago, 1996. (Volume XVIII da Edição Standard das Obras Completas de Sigmund Freud)

FREYRE, G. (1933). Casa Grande \& Senzala. São Paulo: Global, 2006.

HOLANDA, S. B. (1936). Raízes do Brasil. São Paulo: Companhia das Letras, 2014.

JUNG, C. G. (1936). Wotan. Princeton: Princeton University Press, 1978a. (Volume X dos Collected Works of Carl Gustav Jung).

JUNG, C. G. (1957). The Undiscovered Self (Present and Future). Princeton:

Princeton University Press, 1978b. (Volume X dos Collected Works of Carl Gustav Jung).

JUNG, C. G. (1948). The Psychological Foundations of Belief in Spirits. Princeton:

Princeton University Press, 1981. (Volume VIII dos Collected Works of Carl Gustav Jung).

JUNG, C. G. (1938). Psychology and Religion. Princeton: Princeton University Press, 1989. (Volume XI dos Collected Works of Carl Gustav Jung).

JUNG, C. G. (1954). On the Psychology of the Trickster-figure. Princeton: Princeton University Press, 1990. (Volume IX, 1 dos Collected Works of Carl Gustav Jung).

JUNG, C. G. (1932). The Development of Personality. Princeton: Princeton University Press, 1991. (Volume XVII dos Collected Works of Carl Gustav Jung).

JUNG, C. G. (1928). A energia psíquica. Petrópolis: Vozes, 2002.

KANT, E. (1781). Critique de la Raison Pure. Paris: Flammarion, 2006.

KANT, E. (1798). Antropologia de um ponto de vista pragmático. São Paulo: Iluminuras, 2019.

KRAMER, H.; SPRENGER, J. (1486). The Malleus Maleficarum. Translated by Rev. Montague Summers. New York: Dover, 1971.

LEVI, P.; DE BENEDETTI, L. Assim foi em Auschwitz. Testemunhos 1945 - 1986. São Paulo: Companhia das Letras, 2015.

LIMA BARRETO, A. H. (1915). Triste fim de Policarpo Quaresma. São Paulo: Martin Claret, 2011.

MAALOUF, A. Les identités meurtrières. Paris: Grasset, 1998. 
MENEZES, E. D. B. Alceu Amoroso Lima: 'A psicologia do povo' ou 'O homem brasileiro’ - um projeto inconcluso. Revista de Ciências Sociais, v. 29, n. 1-2, p. 19-43, 1998.

NIETZSCHE, F. (1885). Assim falava Zaratustra. Rio de Janeiro: Ediouro, s/d.

NIETZSCHE, F. (1888). Ecce homo - Como se chega a ser o que se é. Lisboa: EuropaAmérica, 1987.

NIETZSCHE, F. (1873). Sobre a verdade e a mentira no sentido extra-moral. São Paulo: Nova Cultural, 1999.

NIETZSCHE, F. (1901). Vontade de potência. Rio de Janeiro: Ediouro, s/d.

PESSOA, F. O eu profundo e outros eus. Rio de Janeiro: Nova Fronteira, s/d.

PESSOA, F. Livro do desassossego. São Paulo: Companhia das letras, 1999.

PRADO JÚNIOR, C. (1942). Formaçáo do Brasil contemporâneo. São Paulo:

Companhia das Letras, 2001.

SANTOS, M. (1987). O espaço do cidadáo. São Paulo: EDUSP, 2014.

SANTOS, M. (2000). Por uma outra globalizaçáo: do pensamento único à consciência universal. Rio de Janeiro: Record, 2001.

SARTRE, J. P. J. P. Sartre commente l'enfer c'est les autres en introduction à Huis Clos. Paris: Gallimard, 2004. CD-ROM.

SOUZA, J. A tolice da inteligência brasileira. Ou como o país se deixa manipular pela elite. São Paulo: LeYa, 2015.

STEINER, J-F. (1966). Treblinka. São Paulo: Abril Cultural, 1976.

TOLSTÓI, L. (1869). Guerra e paz. V. I e II. Tradução de Rubens Figueiredo. São Paulo: Companhia das Letras, 2017.

TURGUEniEV, I. (1862). Pais e filhos. São Paulo: Círculo do Livro, 1984.

UMBELINO, L. A. F. C. Somatologia subjetiva: apercepção de si e corpo em Maine de Biran. Lisboa: Fundação Calouste Gulbenkian, 2010.

VALOIS, R. C. G. Jung et les racines de la guerre. Laval théologique et philosophique, v. 48, n. 2, p. 263-277, 1992.

WANG, H. (1987). Reflections on Kurt Gödel. Cambridge: MIT Press, 1995.

Recebido: 20/11/2017

Aceito: $15 / 9 / 2020$ 
GEWEHR, R. B. 